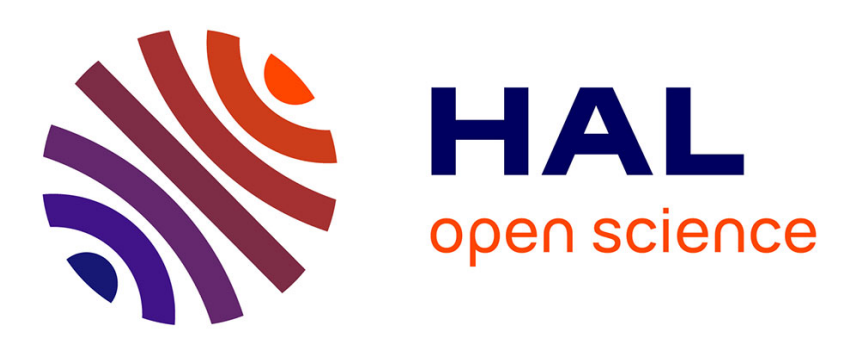

\title{
Hantavirus infection during a stay in a mountain hut in northern Slovakia
}

Hana Zelena Hana, Vlasta Zvolankova Vlasta, Jana Zuchnicka Jana, Katerina Liszkova Katerina, Anna Papa

\section{- To cite this version:}

Hana Zelena Hana, Vlasta Zvolankova Vlasta, Jana Zuchnicka Jana, Katerina Liszkova Katerina, Anna Papa. Hantavirus infection during a stay in a mountain hut in northern Slovakia. Journal of Medical Virology, 2011, 83 (3), pp.496. 10.1002/jmv.21984 . hal-00610733

\section{HAL Id: hal-00610733 https://hal.science/hal-00610733}

Submitted on 24 Jul 2011

HAL is a multi-disciplinary open access archive for the deposit and dissemination of scientific research documents, whether they are published or not. The documents may come from teaching and research institutions in France or abroad, or from public or private research centers.
L'archive ouverte pluridisciplinaire HAL, est destinée au dépôt et à la diffusion de documents scientifiques de niveau recherche, publiés ou non, émanant des établissements d'enseignement et de recherche français ou étrangers, des laboratoires publics ou privés. 


\section{Hantavirus infection during a stay in a mountain hut in northern Slovakia}

\begin{tabular}{|r|l|}
\hline Journal: & Journal of Medical Virology \\
\hline Manuscript ID: & JMV-10-2062.R1 \\
\hline Wiley - Manuscript type: & Research Article \\
\hline Date Submitted by the \\
Author: & 29-Sep-2010 \\
\hline Komplete List of Authors: & $\begin{array}{l}\text { Zelena Hana, Hana; Institute of Public Health, Department of } \\
\text { Virology } \\
\text { Zvolankova Vlasta, Vlasta; Regional Hospital Bohumín, Department } \\
\text { of Internal Diseases } \\
\text { Zuchnicka Jana, Jana; University Hospital, Department of } \\
\text { Haematology } \\
\text { Liszkova Katerina, Katerina; University Hospital, Department of } \\
\text { Anaesthesology and Resuscitation } \\
\text { Papa, Anna; Aristotle University, A' Dept. of Microbiology }\end{array}$ \\
\hline & Hantavirus, Dobrava/Belgrade virus, Slovakia, Czech Republic \\
\hline
\end{tabular}

\section{SCHOLARONE $^{\text {m }}$ Manuscripts}


Table 1. Detection of Hantaan virus (HTNV) and Puumala virus (PUUV) reactive antibodies in patients at different time points using commercial ELISA. N: negative result.

\begin{tabular}{cccccc}
\hline & Day of & \multicolumn{2}{c}{ Index value in } & \multicolumn{2}{c}{ Index value in } \\
& disease & \multicolumn{2}{c}{ HTNV ELISA } & PUUV ELISA \\
& & IgG & IgM & IgG & IgM \\
\hline Patient CT & 7 & 3.21 & 4.05 & $\mathrm{~N}$ & $\mathrm{~N}$ \\
& 76 & 2.41 & 1.46 & $\mathrm{~N}$ & $\mathrm{~N}$ \\
Patient SP & 13 & 3.27 & 6.08 & 1.28 & $\mathrm{~N}$ \\
& 43 & 3.39 & 5.63 & 1.49 & $\mathrm{~N}$ \\
& 85 & 3.57 & 1.49 & 2.14 & $\mathrm{~N}$ \\
\hline
\end{tabular}




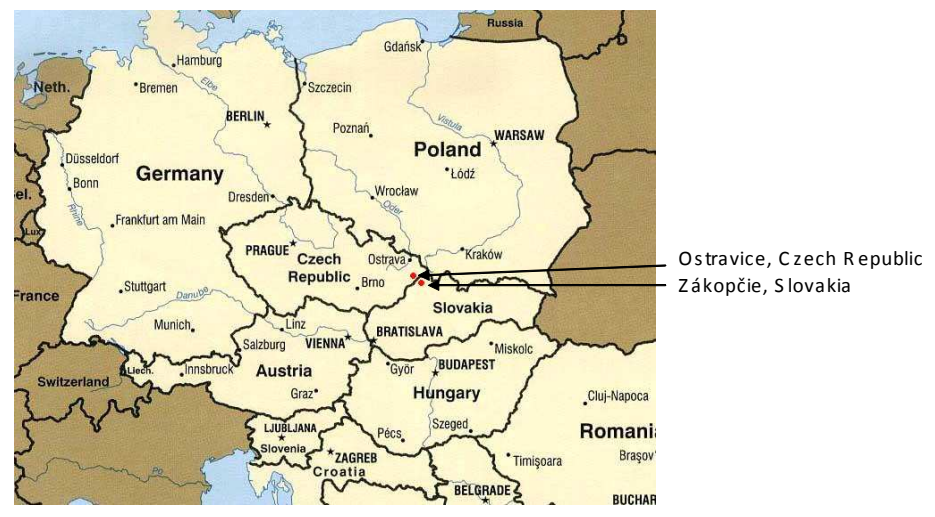




\section{Page 3 of $18 \quad$ Journal of Medical Virology

2

3

4

5

6

7

8

9

10

11

12

13

14

15

16

17

18

19

20

21

22

23

24

25

26

27

28

29

30

31

32

33

34

35

36

37

38

39

40

41

42

43

44

45

46

47

48

49

50

51

52

53

54

55

56

57

58

59

60

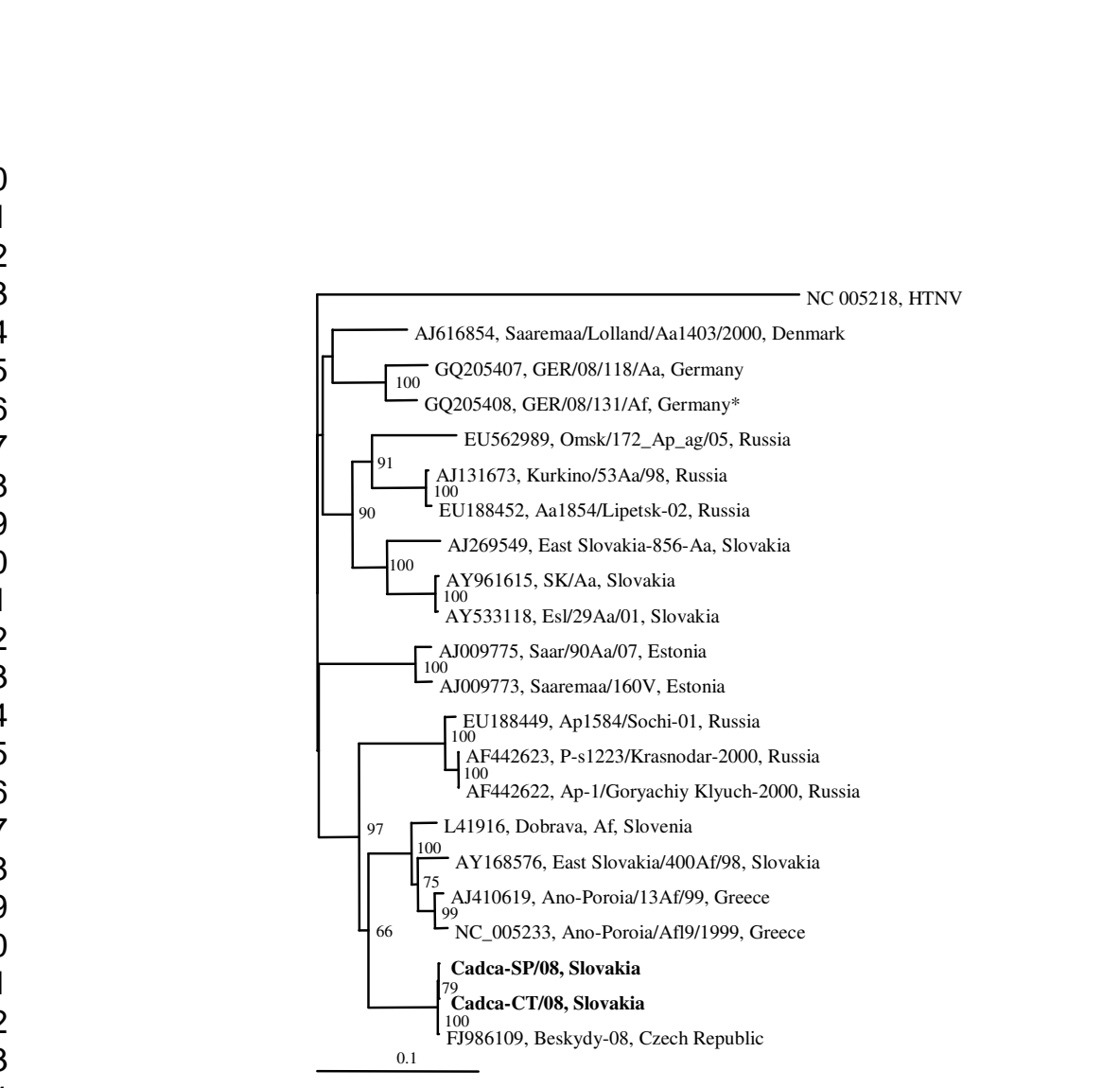

Figure 2A

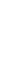

(

.

John Wiley \& Sons 
Figure 2B

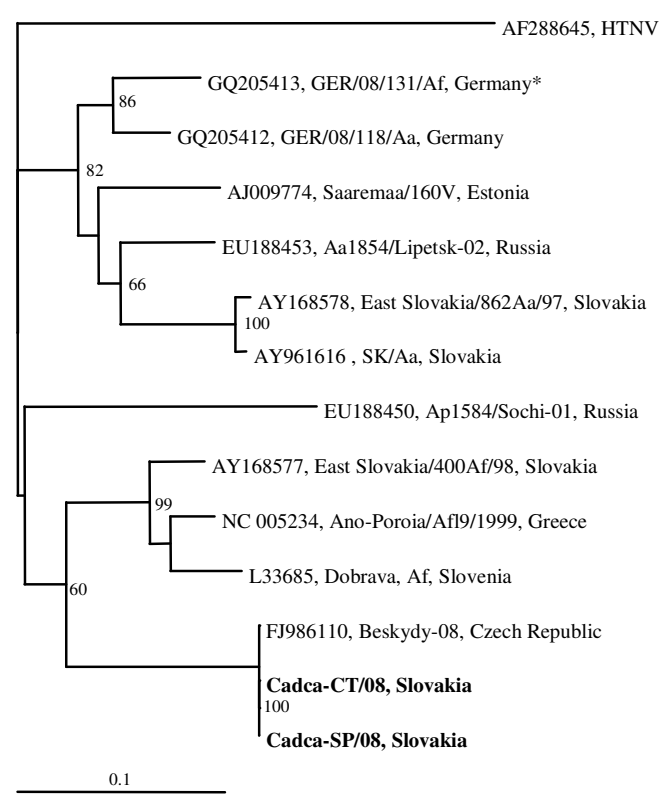


Hantavirus infection during a stay in a mountain hut in northern Slovakia

\author{
Zelena Hana ${ }^{1}$, Zvolankova Vlasta ${ }^{2}$, Zuchnicka Jana ${ }^{3}$, Liszkova Katerina ${ }^{4}$, Papa Anna ${ }^{5}$ \\ ${ }^{1}$ Department of Virology, Institute of Public Health Ostrava, Czech Republic \\ ${ }^{2}$ Department of Internal Diseases, Regional Hospital Bohumín, Czech Republic \\ ${ }^{3}$ Department of Haematology, University Hospital Ostrava, Czech Republic \\ ${ }^{4}$ Department of Anaesthesology and Resuscitation, University Hospital Ostrava, Czech \\ Republic \\ ${ }^{5} \mathrm{~A}^{\prime}$ Department of Microbiology, Medical School, Aristotle University of Thessaloniki, \\ Greece
}

\author{
Abstract: 111 words \\ Text: 2015 words \\ * Author for Correspondence \\ Associate Professor Anna Papa, MD, PhD \\ 1st Dept. of Microbiology, Medical School \\ Aristotle University of Thessaloniki \\ 54124, Thessaloniki, Greece \\ Tel. +30 2310 999006, Fax +302310999151 \\ E-mail: annap@med.auth.gr
}




\begin{abstract}
Hantaviruses in Europe cause human hemorrhagic fever with renal syndrome (HFRS) with various degree of severity. The most severe form is caused by the Dobrava/Belgrade virus (DOBV), associated with the rodent Apodemus flavicollis. During the last decade cases of infection caused by DOBV have been reported in Central Europe. The present study is a report on two Czech patients with severe HFRS who were infected during their stay in a mountain hut in Northern Slovakia. The two patients, combined with a third case observed in the same year in a nearby village in the Czech Republic, suggest that this region in Central Europe has to be considered as endemic for HFRS.
\end{abstract}

Key words: Hantavirus, Dobrava/Belgrade virus, Slovakia, Czech Republic 


\section{INTRODUCTION}

Hantaviruses (genus Hantavirus, family Bunyaviridae) are enveloped, single-stranded RNA viruses with three-segmented genome, causing to humans hemorrhagic fever with renal syndrome (HFRS) in Eurasia and hantavirus pulmonary syndrome (HPS) in the Americas [Jonsson et al., 2010]. Humans are infected mainly by inhalation of infected rodents' excreta. Five hantavirus genotypes associated with rodents are known to circulate in Europe: Puumala virus (PUUV), Dobrava/Belgrade virus (DOBV), Saarema virus (SAAV), Tula virus (TUUV) and Seoul virus (SEOV). The most pathogenic is DOBV, carried by Apodemus flavicollis, with fatality rate up to $10 \%$ [Avsic-Zupanc et al., 1999; Papa and Antoniadis, 2001].

Since the first report of hantavirus infections in Breclav, a Czech town in the South Moravian region [Kobzik and Danes, 1992], only a limited number of HFRS cases have been detected in the Czech Republic [Heyman and Vaheri, 2008]. In August 2008, a 15year boy was infected in Ostravice village, close to the borders of the Czech Republic with Slovakia and Poland, and presented a severe form of HFRS; the patient was hospitalized in the intensive care unit and recovered after 23 days in hospital [Papa et al., 2010]. Application of molecular methods showed that the causative agent was DOBV (strain Beskydy/08), with sequences clustering with respective ones obtained from tissues of A. flavicollis trapped in Slovakia, Greece and Slovenia [Papa et al., 2009]. Two severe HFRS cases in Czech patients were noted after staying in a mountain hut in Slovakia are described. 


\section{PATIENTS AND METHODS}

On November 29, 2008, a group of 15 Czech young males had a party in a mountain hut in Zakopcie village, near Cadca town, in North Slovakia, near the border with the Czech Republic $\left(49^{\circ} 32^{\prime} 19.077^{\prime \prime} \mathrm{N}, 18^{\circ} 23^{\prime} 29.678^{\prime \prime} \mathrm{E}\right)$. The place is $30 \mathrm{~km}$ from the Ostravice village in Czech Republic, where a case caused by DOBV was observed in the summer of 2008 [Papa et al., 2010] (Figure 1).

\section{Case 1 .}

The owner of the hut, a 29-year old hitherto healthy male (patient CT) resident of Bohumín, a small town in the southeastern part of the Czech Republic, went to the hut one day earlier than the rest of the group in order to clean the place. Thirteen days later (December, 10, day 1), he suddenly presented high fever $\left(39^{\circ} \mathrm{C}\right)$ accompanied by headache, diarrhea, vomiting, and lower back and abdominal pain. He received antipyretics according to his physician recommendations. However, his condition deteriorated and on December 15 (day 6), he was admitted to the Department of Internal Diseases in the regional hospital in Bohumín. Three days later, he presented signs of gut and skin bleeding, and the patient developed renal failure with proteinuria, hematuria and hypertension. Hemodialysis was not applied.

The patient presented leucopenia $3.5 \times 10^{9} / 1$ (normal range $4-10 \times 10^{9} / 1$ ), thrombocytopenia $18 \times 10^{9} / 1$ (normal range $150-400 \times 10^{9} / 1$ ), and elevated liver enzymes. Serum urea increased to $21.0 \mathrm{mmol} / \mathrm{l}$ (normal range 2.8-7.2 $\mathrm{mmol} / \mathrm{l}$ ), creatinine to 245 $\mu \mathrm{mol} / \mathrm{l}$ (normal range $62-115 \mu \mathrm{mol} / \mathrm{l}$ ), CRP to $45 \mathrm{mg} / \mathrm{l}$ (normal range $0-10 \mathrm{mg} / \mathrm{l}$ ). $\mathrm{He}$ presented high values of D-dimers (maximum of $18.25 \mathrm{mg} / \mathrm{l}$, normal range $0-0.2 \mathrm{mg} / \mathrm{l}$ ); 
other coagulation parameters were slightly affected. Renal biopsy was suggestive of progressive acute glomerulonephritis, while the thrombocytopenia was considered as immune-associated. As his condition deteriorated rapidly, on day 10 he was transferred to the Intensive Care Unit of the Department of Internal Diseases in the University Hospital in Ostrava. His clinical condition, the renal and liver function, and the laboratory findings returned subsequently to normal and he was discharged from the hospital on day 19, with the diagnosis of hemolytic uremic syndrome. On January 22, 2009, (day 43) during a follow-up examination in a mobile medical facility, a hantavirus infection was suspected.

\section{Case 2}

On December 26, 2008, 28 days after the overnight in the mountain hut, a second member of the group, a 27-year old hitherto healthy male (SP), developed a sudden high fever $\left(40^{\circ} \mathrm{C}\right)$ with profuse diarrhoea, vomiting, headache and vertigo. On day 4 the patient collapsed, and he was admitted to the Department of Internal Diseases of the regional hospital in Bohumín. His condition deteriorated rapidly with hypovolemic and haemorrhagic shock leading to multiorgan failure with predominant renal failure and anuria. His condition was complicated by peripheral edema of the lung. The patient had disseminated intravascular coagulation with heavy bleeding from the needle puncture sites, and then, ongoing bleeding into the adrenal and retroperitoneal space, prompting urgent transfer to the Department of Anaesthesiology and Resuscitation in the University Hospital in Ostrava. High levels of procalcitonin $(88.6 \mu \mathrm{g} / \mathrm{l}$, normal range $0-0.5 \mu \mathrm{g} / \mathrm{l})$ were observed, however, with no evidence of bacterial infection. Hemodialysis and 
arteficial ventilation with tracheostomy were applied. The patient remained comatose for several weeks.

Laboratory findings included leucocytosis 24.4 x $10^{9} / 1$ (normal range 4-10 x $10^{9} / 1$ ), thrombocytopenia $3 \times 10^{9} / 1$ (normal range $150-400 \times 10^{9} / 1$ ), elevated liver enzymes ALT $5.97 \mu \mathrm{kat} / \mathrm{l}$ (normal range 0.15-0.75 $\mu \mathrm{kat} / \mathrm{l}$ ), AST $8.44 \mu \mathrm{kat} / \mathrm{l}$ (normal range 0.15$0.85 \mu \mathrm{kat} / \mathrm{l}$ ). Serum urea increased to $20.3 \mathrm{mmol} / \mathrm{l}$ (normal range $2.8-7.2 \mathrm{mmol} / \mathrm{l}$ ), creatinine to $474 \mu \mathrm{mol} / \mathrm{l}$ (normal range $62-115 \mu \mathrm{mol} / \mathrm{l}$ ). The maximum value of CRP was $127 \mathrm{mg} / \mathrm{l}$ (normal range $0-10 \mathrm{mg} / \mathrm{l}$ ). He revealed extreme values of D-dimers with the maximum value $24.67 \mathrm{mg} / \mathrm{l}$ (normal range $0-0.2 \mathrm{mg} / \mathrm{l}$ ); other coagulatiaon parameters were also affected - prothrombin time $26 \mathrm{~s}$ (normal range 11-16 s), and activated partial thromboplastin time $80.9 \mathrm{~s}$ (normal range 25-35 s).

The condition of the patient was complicated further by lifethreatening nosocomial infections caused by methicillin-resistant Staphylococcus aureus and Candida spp. He was discharged after 68 days in hospital, with most of the time in the Department of Anaesthesiology and Resuscitation.

\section{Serology}

Serum samples taken on days 7 and 76 from patient CT and on days 13, 43 and 85 from patient SP were tested for IgG and IgM antibodies to Hantaan virus (HTNV) and PUUV using ELISA (PROGEN Biotechnik, Heidelberg, Germany). IgM and IgG serology results are considered positive when the index value (optical density divided by the cut off value) is $\geq 2$ and $\geq 1.5$ respectively. 


\section{Extraction of viral RNA and polymerase chain reactions}

Viral RNA was extracted from the earliest available serum samples (taken on day 7 from patient CT and on day 13 from patient SP) using the QIAamp Viral RNA kit (Qiagen, Hilden, Germany) and two RT-nested PCRs were performed using two sets of primers designed to detect hantaviruses associated with rodents of the Murinae subfamily (HTN, DOB, SEO). One primer set (MS120C - MS1170R for the first round and MS364C MS963R for the second round) was used for the amplification of a 590-bp fragment of the $\mathrm{N}$ coding region, and a second primer set (MM1470C - MM2029R for the first round and MM1674C - MM1990R for the second round) was used for the amplification of a 317-bp fragment of partial G1 coding region [Papa et al., 1998; Papa et al., 2009].

Sequencing and phylogenetic analysis

Sequencing of the PCR products was performed in an ABI 3110 genetic analyzer (Applied Biosystems, Foster City, CA). Sequences were aligned by CLUSTAL W, while phylogenetic trees based on S and M segment sequences were constructed by Neighborjoining method using the modules DNAdist, Neighbor and Consense from the PHYLIP software [Felsenstein, 1993] 


\section{RESULTS}

IgM and IgG antibodies against HTNV were detected in all serum samples tested, while antibodies against PUUV were either not detected or the titers were low (Table 1). Serology results suggested that the causative agent was a hantavirus closer antigenically to HTNV. Products of the expected size were obtained by both RT-nested PCRs, while sequencing analysis confirmed that the causative agent was DOBV. The two DOBV sequences (Cadca-CT/08 and Cadca-SP/08) were identical. The closest strain genetically was the Czech strain Beskydy/08, presenting one nucleotide difference in S segment, and no difference in the $\mathrm{M}$ segment. In both $\mathrm{S}$ and $\mathrm{M}$ segment phylogenetic trees, the sequences from both patients and those of the Czech strain (Beskydy/08, Cadca-CT/08, Cadca-SP/08) comprise a distinct subclade in the clade containing DOBV sequences associated with A. flavicollis (Figure 2A and 2B). In the S segment, Slovakian strain differs by $8.7 \%$ and $8.6 \%$ from DOBV strains isolated from A. flavicollis in Greece and Slovenia respectively, and by $9.5 \%$ from strain 400Af/98 from East Slovakia, while in the M segment the Slovakian strain differs by $15.5 \%$ from the strain $400 \mathrm{Af} / 98$, and by $16.7 \%$ and $18.6 \%$ from strains isolated in Greece and Slovenia respectively.

\section{DISCUSSION}

DOBV is highly endemic in the Balkan peninsula, where cases are observed usually in the summer time [Avsic-Zupanc et al., 1999; Papa and Antoniadis, 2001]. In Central and Northern Europe HFRS cases are caused mainly by PUUV [Heyman et al., 2009; Vapalahti et al., 2003]. However, during the last decade, cases vaused by DOBV have been reported in Slovakia, Germany, Poland and the Czech Republic [Klempa et al., 2004; Nowakowska et al., 2009; Papa et al., 2010; Sibold et al., 2001]. The patients of the 
present study were infected in November 2008 in Slovakia, in an area $30 \mathrm{~km}$ far from Ostravice village (South-eastern Czech Republic), where an HFRS case was observed in August 2008, suggesting that this area of Central Europe is an endemic focus for HFRS. The occurrence of the cases in winter could be explained by the fact that rodents entered the hut trying to be protected from the cold. Patient CT presented the disease earlier than patient SP (incubation time 13 days for patient CT versus 28 days for patient SP), most probably because CT inhaled the largest quantity of aerosolized excreta, as he was the first who entered the hut, he cleaned the place and he stayed more time there than the rest group. Two other members of the group tested negative for the presence of $\operatorname{IgG}$ and $\operatorname{IgM}$ antibodies, while the rest refused to be tested. Different factors, including variations in immune response might explain why only patient SP (who stayed the same time as the rest) acquitted the disease. Although the incubation time of patient SP was longer than that of patient CT, his course of the disease was much more severe, accompanied by heavy hemorrhages, and more affected hematological and biochemical parameters. Cytokines and chemokines might be responsible for the different response, which resulted in prolongation of the hospitalization time and further acquisition of nosocomial infections. Preliminary studies have shown that a large number of cytokines and chemokines play a catalytic role in the course and the outcome of HFRS; among them PDGF, RANTES, IP-10, MIP-1b, IL-1ra, IL-9, GM-CSF, IFN-g, eotaxin, and MCP-1 are the most important [Tsergouli et al., 2010].

The Slovakian and the Czech sequences cluster with DOBV strains associated with $A$. flavicollis, and this is in accordance that this virus causes more severe disease than the other hantaviruses in Europe. Studies in rodents in the area will help the identification of 
the exact host of these viruses. It has to be mentioned that DOBV spill-over events have been reported in rodents [Schlegel et al., 2009; Weidmann et al., 2005].

A geographical clustering of sequences has been reported among hantaviruses [Papa et al., 1998; Weidmann et al., 2005]. The strains of the present study differ greatly from those detected in East Slovakia, and, more interestingly, in the S segment they are closer genetically to Greek DOBV strains than to East Slovakian ones. . It should be noted that there are high mountains between Cadca region, the place where patients of the present study were infected, and Kosice, the place were strain East Slovakia/400Af/98 was isolated. Full genome sequencing of the strains will reveal whether recombination or reassortment events took place.

The results of the present study demonstrate that severe DOBV cases are observed in the area where the Czech Republic borders with Slovakia and Poland. Further studies are needed to identify the exact host(s) of the hantavirus strains circulating in that area, while full genome sequence determination will give insight into the genetic characterization of the strains. Apart from this, clinicians have to include HFRS in the differential diagnosis of febrile cases among persons who spend time in the countryside in this region, especially when they present thrombocytopenia and acute renal insufficiency. 


\section{REFERENCES}

Avsic-Zupanc T, Petrovec M, Furlan P, Kaps R, Elgh F, Lundkvist A. 1999.

Hemorrhagic fever with renal syndrome in the Dolenjska region of Slovenia - a 10-year survey. Clin Infect Dis 28:860-865.

Felsenstein J. 1993. PHYLIP (Phylogeny Inference Package) version 3.5c. Distributed by the author. Department of Genetics, University of Washington, Seattle.

Heyman P, Vaheri A. 2008. Situation of hantavirus infections and haemorrhagic fever with renal syndrome in European countries as of December 2006. Euro Surveill 13: pii: 18925.

Heyman P, Vaheri A, Lundkvist A, Avsic-Zupanc T. 2009. Hantavirus infections in Europe: from virus carriers to a major public-health problem. Expert Rev Anti Infect Ther 7:205-217.

Jonsson CB, Figueiredo LT, Vapalahti O. 2010. A global perspective on hantavirus ecology, epidemiology, and disease. Clin Microbiol Rev 23:412-441.

Klempa B, Schutt M, Auste B, Labuda M, Ulrich R, Meisel H, Kruger DH. 2004. First molecular identification of human Dobrava virus infection in central Europe. J Clin Microbiol 42:1322-1325.

Kobzik J, Danes L. 1992. [Laboratory-confirmed cases of hemorrhagic fever with renal syndrome which occurred in Breclav 1989-1990]. Cesk Epidemiol Mikrobiol Imunol 41:65-68.

Nowakowska A, Heyman P, Knap JP, Burzynski W, Witas M. 2009. The first established focus of hantavirus infection in Poland, 2007. Ann Agric Environ Med 16:79-85. 
Papa A, Antoniadis A. 2001. Hantavirus infections in Greece - an update. Eur J Epidemiol 17:189-194.

Papa A, Johnson AM, Stockton PC, Bowen MD, Spiropoulou CF, Alexiou-Daniel S, Ksiazek TG, Nichol ST, Antoniadis A. 1998. Retrospective serological and genetic study of the distribution of hantaviruses in Greece. J Med Virol 55:321327.

Papa A, Zelena H, Barnetova D, Petrousova L. 2010. Genetic detection of Dobrava/Belgrade virus in a Czech patient with Haemorrhagic fever with renal syndrome. Clin Microbiol Infect. 16:1187-1190.

Schlegel M, Klempa B, Auste B, Bemmann M, Schmidt-Chanasit J, Buchner T, Groschup MH, Meier M, Balkema-Buschmann A, Zoller H, Kruger DH, Ulrich RG. 2009. Dobrava-Belgrade virus spillover infections, Germany. Emerg Infect Dis 15:2017-2020.

Sibold C, Ulrich R, Labuda M, Lundkvist A, Martens H, Schutt M, Gerke P, Leitmeyer K, Meisel H, Kruger DH. 2001. Dobrava hantavirus causes hemorrhagic fever with renal syndrome in Central Europe and is carried by two different Apodemus mice species. J Med Virol 63:158-167.

Tsergouli K, Papadimitriou E, Gavana E, Papa A. 2010. Cytokine levels in hemorrhagic fever with renal sydrome caused by Dobrava-Belgrade virus. In: VIII International Conference on HFRS, HPS and Hantaviruses. Athens, Greece. p 206.

Vapalahti O, Mustonen J, Lundkvist A, Henttonen H, Plyusnin A, Vaheri A. 2003. Hantavirus infections in Europe. Lancet Infect Dis 3:653-661. 
Weidmann M, Schmidt P, Vackova M, Krivanec K, Munclinger P, Hufert FT. 2005.

Identification of genetic evidence for Dobrava virus spillover in rodents by nested reverse transcription (RT)-PCR and TaqMan RT-PCR. J Clin Microbiol 43:808812. 
Figure legends

Figure 1. Map showing the site in N. Slovakia where patients of the present study got infected; site in the Czech Republic where a patient of a previous study got infected is also shown.

Figure 2. Phylogenetic trees based on a 590-bp fragment of the S RNA segment (A) and a 317bp fragment of the M RNA segment (B) of hantaviruses. HTNV was used as outgroup. The numbers at the nodes indicate percentage bootstrap replicates of 100 ; values below $60 \%$ are not shown. Horizontal distances are proportional to the nucleotide differences. The scale bar indicates $10 \%$ nucleotide sequence divergence. Sequences in the tree are indicated as GenBank accession number, strain name, country. Strains of the present study are shown in bold. Af: Apodemus flavicollis, Aa: Apodemus agrarius, Ap: Apodemus ponticus. *The sequence GER/09/131/Af originated from a DOBV-Aa spillover infected A. flavicollis rodent. 